\title{
WORKING IN GROUPS FOR COURSEWORK ASSIGNMENTS: THE TERTIARY STUDENTS' PERSPECTIVE
}

\author{
Rosnah Bt. Hj. Mustafa' \\ Pung Wun Chiew² \\ Shirley Michael Slee ${ }^{3}$ \\ ${ }^{12}$ Centre for Language Studies, Universiti Malaysia Sarawak \\ ${ }^{3}$ Sarawak State Education Department \\ 1mrosnah@cls.unimas.my \\ ²wcpung@cls.unimas.my \\ 3abadiey_paradise@yahoo.com
}

\begin{abstract}
The study examined undergraduates' perception of group work in doing coursework assignments. It specifically investigated students' perceptions of the usefulness of group work in doing assignments; identified reasons which influence students' preference or non-preference for group work in doing assignments; determined students' expectations of instructor's roles in group work; and compared students' perceptions of group work across ethnic groups. A 39-item questionnaire was distributed to 200 students in a Malaysian public university. The findings showed that a majority of students viewed group work positively due to lesser time required to accomplish given tasks and increased interpersonal gains. Some students however disapproved of group work for several reasons including the difficulty to find mutually agreed time for discussions, domination of some group members, and the existence of slackers in the group. One major aspect highlighted in the study was students' need for continuous instructor support and assistance when group work was assigned.
\end{abstract}

Keywords: group work, collaborative learning, assignments

Introduction

The challenges of teaching and learning are diverse and teachers and educators are constantly diversifying their teaching techniques to ensure active and meaningful learning takes place, both inside and outside the boundaries of a classroom or lecture theatre. A common Malaysian classroom, whether at school or tertiary level, consists of students from different ethnic and cultural backgrounds. Such diversity often requires teachers and educators to use a variety of teaching techniques to 
ensure maximum learning takes place and at the same time enhance unity. One of the most commonly used techniques is group work.

The advantages of group work have been acknowledged and researched by many (Baines et al., 2004; Burdett \& Hastie 2009; Chickering \& Gamson, 1987; Felder \& Brent 2007; Hennessy \& Evans, 2006; Kennett, Stedwill, Berrill, \& Young, 1996; Millis \& Cottel as cited in Payne \& Monk-Turner, 2006; Johnson \& Johnson, 1989; Johnson, Johnson, \& Smith, 1991; Slavin, 2006). The ability to work in a team or group is not only beneficial in classroom settings, but also at the workplace. Capelli and Bogovsky (as cited in Cohen \& Bailey 1997) and Cranmer (as cited in Burdett \& Hastie, 2009) stressed that many employers seek new graduates who have the ability to work in a team to achieve the companies' goals. Academics too often favour group work for its anticipated reduction in marking load (Burdett \& Hastie, 2009, p. 1). The importance of working in a team is also stressed by Chickering and Gamson (1987) who argued that:

Learning is enhanced when it is more like a team effort than a solo race. Good learning, like good work, is collaborative and social, not competitive and isolated. Working with others often increases involvement in learning. Sharing one's own ideas and responding to others' reactions improves thinking and deepens understanding. (para 3)

According to Terenzini, Cabrera, Colbeck, Parente, and Bjorklund (2001) group work produces greater gains in student learning. Panitz (1996) stressed that group work encourages sharing of authority and acceptance of responsibility among group members for the group's actions. Group work encourages the sharing of knowledge and ideas, and at the same time promotes understanding and tolerance among group members regardless of differences or similarities in ethnicity, ability, and educational background. In a study involving 4000 pupils aged between five and 14 by the Institute of Education at London University (Smith, 2006), researchers found that children working in groups made rapid progress and were more focused on their work. In addition, group work also encouraged more thoughtful discussions between the children. Tok (2006) conducted a study on the effect of cooperative learning on 210 Form Four students learning literature in a Malaysian secondary school. The results showed cooperative learning benefitted a majority of respondents, both academically and socially. In subjects such as literature, it is imperative that students voice out their ideas and share their thoughts on the texts being studied. Vaughn (2002) studied the effects of cooperative learning on the achievement development and attitude towards mathematics among students of other colour. The study, which adopted Slavin's (2006) STAD method, showed that those involved in the cooperative learning method demonstrated higher achievement and positive attitudes towards mathematics. In a study similar to that of Slavin, Effandi Zakaria, Lu, and Md. Yusoff Daud (2010) found that cooperative learning improved students' mathematics ability and increased their positive attitudes towards the subject. In their study involving 82 Form One students in the state of Sarawak in Malaysia, students in the experimental group showed better 
achievement and higher motivation to learn mathematics compared to those in the control group. They concluded that students in the experimental group not only exhibited higher levels of motivation and self-confidence in solving mathematic tasks, but performed well in their post-test as a result of working together with their team members.

Despite the many advantages highlighted, there are also constraints that may hinder students from working effectively in a group. While many academics would like to include group work as an effective teaching technique, there is often hesitation because of bad experiences when the group has fallen apart or has failed to complete the task. One of the constraints is the group size. There are various views on the ideal number of students in a group. Davies (1993) stated that a group consisting more than five members decreases each member's opportunity to participate actively. Conversely, Hennessy and Evans (2006) reported that clusters of four to seven students in a group are considered ideal. Rice (as cited in Jacques, 1995) proposed having six members in a group. Douglas (2000) argued that having too many people in a group may limit the chances of individual group member to contribute ideas. He believed that having lesser members in a group provides sufficient time for sharing and debating ideas.

Studies have also shown that group work is not always perceived positively by students for one reason or another (Burdett \& Hastie 2009; Payne \& MonkTurner, 2006). Livingstone and Lynch (as cited in Burdett \& Hastie, 2009, p. 62) argued that a group which is dysfunctional will result in collaborative efforts failing and compromised learning outcome. Volet and Mansfield (as cited in Burdett \& Hastie 2009, p. 62) maintained that such negative thoughts on group work may result in avoidance of working in groups in the future. However, in spite of the growing number of studies including those that examined collaborative work activities and practices in Malaysian schools (Burdett \& Hastie 2009; Chickering \& Gamson 1987; Effandi Zakaria et al., 2010; Hennessy \& Evans 2006; Kennett et al., 1996; Millis \& Cottelas cited in Payne \& Monk-Turner, 2006; Johnson \& Johnson, 1989; Johnson et al., 1991; Smith, 2006; Tok, 2006), there have been very few studies investigating the perspectives of Malaysian undergraduates on this matter. More research is needed to look into undergraduates' perceptions of group work and how it benefits them. It is important to study such perceptions as Malaysian undergraduates are expected to develop good team work skills to prepare them for the working world, especially when many employers stress the importance of team work in achieving company goals. In addition, as group work is very common across faculties and universities, it is therefore apt to conduct a study on students' perspectives. With these concerns in mind, this study examined undergraduates' perceptions of group work in doing assignments. It specifically

1. investigated students' perceptions on the usefulness of group work in doing assignments;

2. identified the reasons that influence students' preference or non-preference for group work in doing assignments;

3. explored students' expectations of instructor's roles in group work; and

4. compared students' perceptions of group work across ethnic groups. 


\section{Method of Study}

Data were collected through a 39-item questionnaire adapted from Kaenzig et al. Anderson (2007), Payne and Monk-Turner (2006), and Kromrey and Purdom (1995). The questionnaire was divided into five sections, namely, student demographic profile, their perceptions of group work, the advantages and disadvantages of group work, and their perceptions of instructor's role in group work. The respondents were asked to rate their preference according to a Likert scale from 1 (Strongly Agree) to 5 (Strongly Disagree).

The subjects for the questionnaire comprised 200 third year and fourth year undergraduate students from a local university, with 38 male students and 162 female students. In terms of racial distribution, 77 were Malay, 96 Chinese, and 27 Indians and others. The rationale for choosing only these subjects was to ensure that they had acquired enough experience working in groups in completing assignments. A pilot study was done on 10 respondents to ensure the reliability of the questionnaire. Once the pilot testing was done, 200 questionnaires were distributed to the respondents. To ensure that the respondents had ample time to think through their responses, the questionnaire was collected after two weeks.

Descriptive statistics was used to analyse data for each section. The analysis was done using SPSS version 14. For section A which included data on gender, ethnicity, programme and year of study, the frequency was keyed in for each category. For sections B, C, D, and E, the options "Strongly Agree" and "Agree' were combined as one and similarly "Strongly Disagree" and "Disagree" were categorised as "Disagree" for the sole purpose of getting the information on the agreement or disagreement. The study, however, did not aim to measure the level of agreement or disagreement of the respondents towards the items in the questionnaire. As such, the responses for sections B to E were presented as "Agree", "Neutral", and "Disagree". The data obtained were presented in the form of frequency, percentage and mean for each item.

\section{Results and Discussions}

\section{Students' perceptions of group work}

As Table 1 shows, the respondents generally viewed group work as useful when writing group assignments. All positive items on perceptions of group work (statements 1-8) had the agreement of more than half of the respondents. In contrast, less than half of the respondents agreed with statements 9 and 10, which are negative statements about group work. A majority of respondents (82\%) felt they learned new information from group members and more than three quarter of the respondents (78.5\%) also agreed they could share ideas with their group members. These findings confirm findings obtained in Payne and Monk-Turner's (2006) study, where students gained new knowledge from group members when doing group projects. These findings also concur with McManus and Gettinger's (1997) study who found that students shared ideas when they worked together. 
Table 1

Percentage of students agreeing and disagreeing with usefulness of working in groups for assignments

\begin{tabular}{|c|c|c|c|c|}
\hline Item & $\begin{array}{l}\text { Usefulness of working in groups } \\
\text { for assignments }\end{array}$ & $\begin{array}{l}\text { Strongly } \\
\text { Agree and } \\
\text { Agree } \\
(\%) \\
\end{array}$ & $\begin{array}{l}\text { Neutral } \\
(\%)\end{array}$ & $\begin{array}{c}\text { Strongly } \\
\text { Disagree and } \\
\text { Disagree } \\
(\%) \\
\end{array}$ \\
\hline 1. & $\begin{array}{l}\text { I learned some information from } \\
\text { my group members. }\end{array}$ & 82.0 & 9.5 & 8.5 \\
\hline 2. & $\begin{array}{l}\text { I can share ideas with my group } \\
\text { members. }\end{array}$ & 78.5 & 15 & 6.5 \\
\hline 3. & $\begin{array}{l}\text { I feel more comfortable doing } \\
\text { group assignments in a small } \\
\text { group. }\end{array}$ & 77.5 & 11.5 & 11.0 \\
\hline 4. & $\begin{array}{l}\text { I have the opportunity to interact } \\
\text { clearly with others. }\end{array}$ & 70.5 & 17.5 & 12.0 \\
\hline 5. & $\begin{array}{l}\text { I am able to use my own words to } \\
\text { discuss material, listening to new } \\
\text { ideas and examples. }\end{array}$ & 67.5 & 26.0 & 6.5 \\
\hline 6. & $\begin{array}{l}\text { I am able to retain what I have } \\
\text { learned. }\end{array}$ & 57.5 & 32.5 & 10.0 \\
\hline 7. & $\begin{array}{l}\text { I have a great deal of confidence to } \\
\text { express my point view. }\end{array}$ & 57.0 & 35.0 & 8.0 \\
\hline 8. & $\begin{array}{l}\text { I find that it saves time in making } \\
\text { decision on difficult tasks. }\end{array}$ & 53.5 & 32.5 & 14.0 \\
\hline 9. & $\begin{array}{l}\text { I do a lot of organising and setting } \\
\text { people together to work on group } \\
\text { tasks. }\end{array}$ & 42.5 & 40.0 & 17.5 \\
\hline 10. & $\begin{array}{l}\text { I find that my group members do } \\
\text { not contribute to the assignments. }\end{array}$ & 22.5 & 37.5 & 40.0 \\
\hline
\end{tabular}

The results also revealed that a majority of respondents (77\%) felt comfortable working in groups. Most of them agreed they had the opportunity to interact clearly with others (70.5\%), freely discuss and listen to new ideas and examples (67.5\%), and demonstrate their confidence in speaking out their ideas (57\%). These findings are similar to the findings in a study conducted by Hennessy and Evans (2006). Hennessy and Evans found that students felt they had a right to express their views and exhibit some level of authority during small group learning in the classroom. It was also found that the students were confident in expressing themselves and had no inhibition to interact and voice out their ideas. According to Kromrey and Purdom (1995), the ability to discuss freely, listen to others' ideas, understand how other people think, and reach meaningful conclusions are important aspects of active learning. In addition, Kromrey and Purdom also stated that with the cooperative effort of the group, little time was required when making decisions when solving difficult tasks. The findings of this study also support Kromrey and Purdom's view where 53.5\% of the respondents agreed that group work enabled them to save time in making decisions on a difficult task. More than 
half of the respondents $(57.5 \%)$ also indicated that they could retain what they had learned. This finding corroborates with Glass and Putnam's study (as cited in Watson, 1995 ) in that students could learn and remember information for long periods of time during cooperative learning.

In terms of the respondents' perceptions on their role in organising and setting people together to carry out group tasks, $42.5 \%$ agreed that they had to play that role. This could be due to the fact that some group members preferred to act only upon instruction from another group member. Another possible reason is nonappointment of a group leader when the group was first formed, and subsequently, all group members were unsure of their own role and responsibilities.

With regard to group members' contribution to group work, $40 \%$ of the respondents agreed that their group members contributed to group assignments. However, $22.5 \%$ also agreed that their group members did not contribute to the assignment and only benefitted from other group members' hard work. Nevertheless, respondents' perceptions of group work are related to reasons for their preference and non-preference for group work in group assignments. These reasons will be discussed in the following two sections.

In sum, the respondents generally perceived group work as useful and positive, specifically with regard to gaining new information from group members, sharing ideas with group members, retaining information learned, and having the opportunity to interact with others. The respondents also felt that they were comfortable working in groups and that group work enabled them to save time when working on difficult tasks. Nonetheless, some respondents felt that they had to be proactive in organising and setting people together to carry out the tasks. This indicates that group members have different personalities: while some members act upon their own initiative, others need to be prodded into action. As such, this implies that appointing a group leader when a group is first formed is necessary.

\section{Reasons influencing students' preference or non-preference for group work in doing assignments}

Table 2 shows the results for reasons which influence students' views of group work. In general, the respondents viewed the factors tha

$t$ influenced them to do group work positively. More than half of the respondents agreed that they liked group work because they had good working relationship with their group members (statement 1-73\% and statement $4-61.5 \%$ ) and they could finish the group assignment within the allocated time (61.5\%). The link between good working relationship and ability to complete group tasks within stipulated time frame is also evident in Kromrey and Purdom's (1995) study involving 143 college students who completed a group project when the study was conducted. 
Table 2

Percentage of students agreeing and disagreeing with reasons for preferring working in groups for assignments

\begin{tabular}{|c|c|c|c|c|}
\hline & $\begin{array}{l}\text { Reasons for preferring working in } \\
\text { groups for assignments }\end{array}$ & $\begin{array}{l}\text { Strongly } \\
\text { Agree and } \\
\text { Agree } \\
\text { (\%) }\end{array}$ & $\begin{array}{c}\text { Neutral } \\
\text { (\%) }\end{array}$ & $\begin{array}{c}\text { Strongly } \\
\text { Disagree } \\
\text { and Disagree } \\
\text { (\%) }\end{array}$ \\
\hline 1. & $\begin{array}{l}\text { I can build good rapport with my } \\
\text { friends/coursemates. }\end{array}$ & 73.0 & 18.0 & 9.0 \\
\hline 2. & $\begin{array}{l}\text { I can share my workload with other } \\
\text { group members. }\end{array}$ & 69.5 & 18.5 & 12.0 \\
\hline 3. & $\begin{array}{l}\text { I am able to contribute to the group in } \\
\text { a meaningful way. }\end{array}$ & 66.0 & 28.0 & 6.0 \\
\hline 4. & $\begin{array}{l}\text { I feel that I work well with the } \\
\text { members of my team. }\end{array}$ & 61.5 & 30.5 & 8.0 \\
\hline 5. & $\begin{array}{l}\text { I find that doing assignments in group } \\
\text { help our group to complete our work } \\
\text { within the allocated time. }\end{array}$ & 61.5 & 22.5 & 16.0 \\
\hline 6. & $\begin{array}{l}\text { I find that doing group work help me } \\
\text { to participate actively in discussion. }\end{array}$ & 58.5 & 27.5 & 14.0 \\
\hline 7. & $\begin{array}{l}\text { I am satisfied with the outcome of } \\
\text { group assignments than with the task I } \\
\text { do on my own. }\end{array}$ & 49.0 & 32.0 & 19.0 \\
\hline 8. & $\begin{array}{l}\text { I like to do group assignments with } \\
\text { friends of same ability only. }\end{array}$ & 22.0 & 23.0 & 55.0 \\
\hline 9. & $\begin{array}{l}\text { I like to do group assignments with } \\
\text { friends of same race only. }\end{array}$ & 21.0 & 26.0 & 53.0 \\
\hline 10. & $\begin{array}{l}\text { I like to do group assignments with } \\
\text { friends of same gender only. }\end{array}$ & 16.0 & 26.5 & 57.5 \\
\hline
\end{tabular}

A majority of respondents agreed that group work enabled them to share the workload with the other members (69.5\%), participate actively (58.5\%), and contribute meaningfully $(66 \%)$ during discussions. These findings are parallel with the research conducted by Hennessy and Evans (2006) where it was found that small-group discussion process was less intimidating for community college students as witnessed in their ability to express their opinions and be more engaged in the discussions.

In terms of satisfaction level on group assignments' outcome, $49 \%$ of the respondents agreed they were more satisfied with the outcome of group assignments than tasks done individually, while only $19 \%$ disagreed. In a study conducted by Vaughan (2002) on students in the United States, the findings showed that learning in groups has a positive effect on students' academic performance. The study revealed that these students performed better academically in groups than individually. This implies that group learning may improve students' academic achievement. 
With regards to respondents' preferences on group members, $55 \%$ of respondents preferred working with members of mixed abilities, followed by $53 \%$ who liked to work with members of different ethnicity, and $57 \%$ who enjoyed working with both male and female group members. This implies that the respondents were not in favour of working with members who were of the same ability, ethnic group, and gender. As such, these students would have the added advantage of having no difficulty working with people of different gender and races, and with different abilities while simultaneously enhancing their interpersonal skills in the process (see McManus \& Gettinger, 1997).

The findings also revealed that having good working relationship with group members and being able to share the workload with the other members were the two main factors that explained why a majority of respondents preferred group work in completing assignments. The respondents felt that group work allowed them to accomplish an assignment within the allocated time, and that it enabled them to participate actively and contribute meaningfully in group discussions. As such, a majority of respondents also perceived that the outcome of a group work was more satisfactory than the outcome of a work or a task done individually.

Among the factors that influenced students' non-preference for group work, two factors had the agreement of more than half of the respondents: the difficulty of finding a suitable time for all members to meet $(52.5 \%)$ and the existence of dominating group members (52\%). The problem of scheduling difficulties was also reported in Hennessy and Evans' (2006) study where it was generally acknowledged by the student participants as the reason for their resistance to small group learning.

The next four main factors why students do not prefer group work were the presence of a "slacker" or "free-rider" in the group (47.5\%), little cooperation from other group members (46.5\%), difficulty in reaching an agreement among group members (40\%), and the longer time required to complete a task in groups (35.5\%). All these four factors suggest that certain qualities are necessary for a group work to succeed. Vaughan (2002) stated that collaborative skills such as social, leadership, decision making, and communication skills are necessary in group work.

Table 3

Percentage of students agreeing and disagreeing with reasons for not working in groups for assignments

\begin{tabular}{|c|c|c|c|c|}
\hline Item & $\begin{array}{l}\text { Reasons for not preferring group work } \\
\text { in group assignments }\end{array}$ & $\begin{array}{l}\text { Strongly } \\
\text { Agree and } \\
\text { Agree } \\
(\%)\end{array}$ & Neutral (\%) & $\begin{array}{l}\text { Strongly } \\
\text { Disagree } \\
\text { and } \\
\text { Disagree } \\
(\%)\end{array}$ \\
\hline 1. & $\begin{array}{l}\text { It is difficult to find a common time to } \\
\text { meet to discuss the group assignment. }\end{array}$ & 52.5 & 25.0 & 22.5 \\
\hline 2. & $\begin{array}{l}\text { There are group members who like to } \\
\text { dominate the discussion. }\end{array}$ & 52.0 & 30.5 & 17.5 \\
\hline 3. & $\begin{array}{l}\text { At least one group member is a slacker } \\
\text { or a free-rider. }\end{array}$ & 47.5 & 33.5 & 19.0 \\
\hline 4. & The other members of the group give & 46.5 & 34.5 & 19.0 \\
\hline
\end{tabular}




\begin{tabular}{|c|c|c|c|c|}
\hline 5. & $\begin{array}{l}\text { It is difficult to reach an agreement while } \\
\text { doing group work. }\end{array}$ & 40.0 & 37.0 & 23.0 \\
\hline 6. & $\begin{array}{l}\text { It takes longer time to complete the task } \\
\text { in a group. }\end{array}$ & 35.5 & 35.5 & 29.0 \\
\hline 7. & $\begin{array}{l}\text { I am forced to accept the conclusion } \\
\text { made by the majority in the group. }\end{array}$ & 26.5 & 41.5 & 32.0 \\
\hline 8. & $\begin{array}{l}\text { I have been taken advantage of by my } \\
\text { group members. }\end{array}$ & 26.5 & 37.0 & 36.5 \\
\hline 9. & I do most of the work in my group. & 20.0 & 44.0 & 36.0 \\
\hline 10. & $\begin{array}{l}\text { I feel left out of the team's decision } \\
\text { making. }\end{array}$ & 15.5 & 33.5 & 51.0 \\
\hline
\end{tabular}

The remaining four possible reasons for students' non-preference for group work were generally not applicable to the respondents. Only $26.5 \%$ of the respondents agreed that they were forced to accept the conclusion made by the group or taken advantage of by other group members, while $20 \%$ of them perceived they did most of the work in the group and $15.5 \%$ felt left out of the team's decision making process. This finding implies that although these are possible reasons for students' non-preference for group work, they are not common experiences of the students in this study.

\section{Students' perceptions of instructor's role in group work}

The results showed that most of the respondents agreed that the instructor should assist them at the beginning of group work (65.5\%) and conduct a follow-up discussion (60\%). This finding correlates with the findings in Kromrey and Purdom's (1995) study where students reported needing help from the instructor as part of their cooperative learning experience. Students also reported that they required follow-up discussion at the end of the group work with the instructor who would answer their queries, clarify points and address related issues and problems.

Table 4

Percentage of students agreeing and disagreeing with instructor roles in group work

\begin{tabular}{|c|c|c|c|c|}
\hline Item & Instructor roles in group work & $\begin{array}{l}\text { Strongly } \\
\text { Agree and } \\
\text { Agree } \\
(\%)\end{array}$ & $\begin{array}{l}\text { Neutral } \\
(\%)\end{array}$ & $\begin{array}{c}\text { Strongly } \\
\text { Disagree } \\
\text { and } \\
\text { Disagree } \\
\text { (\%) }\end{array}$ \\
\hline 1. & $\begin{array}{l}\text { The instructor should assist me at the } \\
\text { beginning of the group work. }\end{array}$ & 65.5 & 24.5 & 10.0 \\
\hline 2. & $\begin{array}{l}\text { The instructor should have follow-up } \\
\text { discussion at the end of the group work. }\end{array}$ & 60.0 & 29.5 & 10.5 \\
\hline 3. & $\begin{array}{l}\text { The instructor should be the source of } \\
\text { input. }\end{array}$ & 55.5 & 33.0 & 11.5 \\
\hline
\end{tabular}



4. The instructor should participate in the group discussion.
5. I do not need the instructor's assistance; I simply need him/her to give directions and
39.5
26.5
38.0 materials.

More than half of the respondents (55.5\%) also felt that the instructor should be the source of information. However, only $39.5 \%$ of the respondents agreed that the instructor should participate in the group discussions. As such, this implies that respondents were keen to receive information and knowledge from their instructor, but were opposed to the instructor's involvement in their discussion. This could be attributed to the high level of respect students have for their instructor as an expert in the field and the knowledge source. The respondents, however, reported that they felt uncomfortable if the instructor participated in the group discussion. This is because they feared receiving negative comments and feedback from their instructor. The finding corroborates with Livingstone's (2002) assertion that negative comments can be embarrassing for some group members, which can hamper group functioning. A total of $38 \%$ of respondents also disagreed with the statement that they did not require instructor's assistance and that simple instructions and few materials from the instructor would be sufficient. This implies that students still need a certain amount of guidance from their instructors in group work.

The findings showed that there was no significant difference between male and female students' perceptions of group work and preference for certain instructor roles in the other aspects of group work. Male students had slightly higher perceptions regarding the usefulness of group work for group assignments. However, compared to the female respondents, they perceived group work negatively with regard to group members' contribution in completing assignments. This finding contradicts the finding obtained Kaenzig et al.'s (2007) study, where female college students reported having negative experiences working in groups compared to male students. As such, this supports Gallos' (as cited in Kaenzig et al., 2007) claim that women and men do not have parallel experiences when it comes to group work.

A majority of respondents viewed it was necessary for the instructor to assist them at the beginning of group work and conduct a follow-up discussion. The instructor was also generally viewed as the source of information, an important guide for the group, but not as an active member in group discussions.

\section{Comparison of students' perceptions of group work across ethnic groups}

Table 5 shows that Chinese students were found to have a more positive perception of group work in facilitating better learning retention compared to Malay students and students of other races. In terms of students' perceptions of themselves being the ones organising and setting people to carry out group tasks, Chinese and Malay students were found to hold this belief more strongly than students of other races. This implies that Chinese and Malay students are more proactive in their studies and prefer to start their work shortly after they receive the assignment tasks. 
The findings also showed that Chinese students were more likely to agree that group work enabled group tasks to be completed on time than students of other races. This contradicts the findings obtained in Park's (1997) study on Chinese, Filipino, Korean, Vietnamese, and Anglo students in American secondary schools. The study revealed that Korean, Chinese, and Anglo students showed negative preferences for group learning. The difference in findings between the two studies could be due to the gap between them (more than ten years apart). The changing perspectives on education could be a possible reason why Chinese students in this study have a more positive view of group work. Compared to students of other races, Chinese students were also found to have a more positive perception of group work, claiming that it enabled them to participate actively in group discussions. Malay students, however, did not view this aspect of group work positively as they did not think active participation in discussions was a result of working in groups.

Table 5

Students' perceptions of group work across ethnic groups

\begin{tabular}{|c|c|c|c|c|c|c|}
\hline \multirow{2}{*}{$\begin{array}{l}\text { Benefits of working across ethnic } \\
\text { gorups }\end{array}$} & \multicolumn{2}{|c|}{ Malay } & \multicolumn{2}{|c|}{ Chinese } & \multicolumn{2}{|c|}{ Others } \\
\hline & Mean & SD & Mean & SD & Mean & SD \\
\hline $\begin{array}{l}\text { 1. Facilitating better learning } \\
\text { retention }\end{array}$ & 1.85 & 1.22 & 2.40 & 1.48 & 1.74 & 1.13 \\
\hline $\begin{array}{l}\text { 2. Ability to organise and set people } \\
\text { to work on group tasks }\end{array}$ & 2.56 & 1.42. & 2.66 & 1.53 & 1.81 & 1.27 \\
\hline $\begin{array}{l}\text { 3. Facilitating the completion of task } \\
\text { within the allocated time }\end{array}$ & 1.77 & 1.34 & 2.42 & 1.58 & 2.25 & 1.67 \\
\hline $\begin{array}{l}\text { 4. Group discussions are facilitated by } \\
\text { group work }\end{array}$ & 1.83 & 1.25 & 2.40 & 1.60 & 2.03 & 1.45 \\
\hline $\begin{array}{l}\text { 5. Preference of working with } \\
\text { members of the same race }\end{array}$ & 3.87 & 1.55 & 3.12 & 1.60 & 4.25 & 1.60 \\
\hline $\begin{array}{l}\text { 6. Working with members of the } \\
\text { same ability }\end{array}$ & 3.93 & 1.56 & 3.18 & 1.69 & 4.03 & 1.40 \\
\hline $\begin{array}{l}\text { 7. More time needed to complete } \\
\text { group assignment }\end{array}$ & 3.29 & 1.61 & 2.55 & 1.50 & 2.25 & 1.48 \\
\hline $\begin{array}{l}\text { 8. Feeling left out of the group's } \\
\text { decision making }\end{array}$ & 3.93 & 1.44 & 3.62 & 1.42 & 3.14 & 1.56 \\
\hline $\begin{array}{l}\text { 9. Meeting at a common time was } \\
\text { difficult }\end{array}$ & 2.77 & 1.63 & 1.98 & 1.50 & 2.25 & 1.67 \\
\hline $\begin{array}{l}\text { 10. Instructor's need to have follow-up } \\
\text { discussions }\end{array}$ & 2.02 & 1.26 & 2.22 & 1.56 & 1.37 & 0.79 \\
\hline
\end{tabular}

With regard to students' preference on working with members of the same race, students of other races preferred working in groups with members of the same race. This could be due to the fact that they belonged to racial minority groups and working with members of the same race would give them a better sense of belonging. This finding corroborates Payne and Monk-Turner's (2006) claim that students from racial minority groups often confront racist attitudes of the majorities. 
Working with group members of the same race gives these students some sense of security since they do not have to deal with possible racist sentiments when working with members of other races. Similarly, compared to Malay and Chinese students, students of other races preferred to work with group members who were of the same ability. This could be due to the ease of working with them and their own sense of inferiority when working with higher ability students.

Malay students, on the other hand, reported that they needed more time to complete a group assignment compared to Chinese students and students of other races. They also reported being left out from the group's decision making process, claiming that they were the ones doing most of the work and it was difficult to meet at a common time for group discussions. This may explain Malay students' nonpreference for group work.

With regard to students' perceptions of the instructor's role in group work, Malay and Chinese students claimed that they wanted the instructor to conduct follow-up discussions. In terms of students' perceptions of group work based on ethnicity, Chinese students viewed group work more positively. They maintained that group work enabled them to retain knowledge, complete group tasks on time, and allow them to participate actively in discussions. Malay students, as mentioned earlier, felt that it was difficult for all group members to meet at a common time to discuss and that group work required more time to complete. They also felt that they had to do most of the work while being left out of the group's decision making process. When choosing group members, however, students of other races had higher preference for group members of the same race and ability compared to Chinese and Malay students. With regard to students' perception of themselves being the ones organising and setting people to work on group tasks, both Chinese and Malay respondents held this belief more strongly than students of other races. The findings imply that undergraduates view group work positively. However, their perceptions of group work are also heavily influenced by factors such as the difficulty to arrange a common time to meet for the group discussion, as well as group dynamics such as group members' gender, race, ability, and the kind of personalities they have. The findings also indicate that the role of the instructor is important - not as a participating member, but as a person who oversees the discussion from start to finish.

\section{Conclusion}

The findings revealed that students were very positive about the merits of group work, as working in a group benefited them in many ways, for example, it helped improve their interpersonal skills by learning, interacting, and sharing ideas with each other. Two main factors highlighted as the advantages of group work are the ability to share the workload in doing assignments and develop good working relationships among group members. Most of the respondents agreed that the instructor should assist them at the beginning of group work and conduct a followup discussion. In terms of students' perceptions of group work based on ethnicity, Chinese students were found to view group work more positively. Compared to 
students of other races, Malay and Chinese students preferred the instructor to conduct follow-up discussions.

The majority preference for group work in doing assignments suggests that it can be used as a means of assisting students in completing their assignments and training them to work with others. Many employers today expect graduates to have the ability to work in a team in accomplishing work related tasks and achieving company goals. Thus, it is imperative that instructors and educators provide wellplanned group work tasks as a way of helping undergraduate students to meet these expectations and preparing them for the working world in the process.

\section{References}

Baines, E., Blatchford, P., \& Chowne, A. (2007). Improving the effectiveness of collaborative group work in primary schools: Effects on science attainment. British Educational Research Journal, 33(5), 663-680.

Burdett, J., \& Hastie, B. (2009). Predicting satisfaction with group work assignments. Journal of University Teaching and Learning Practice, 6(1), 61-71.

Chickering, W. A., \& Gamson, Z. F. (1987). Seven principles in good practice in undergraduate education. Retrieved from http://www/lonestar.edu/multimedia/SevenPrinciples.pdf

Cohen, S. G., \& Bailey, D. E. (1997). What makes team work: Group effectiveness research, from shop floor to the executive suite. Journal of Management, 23, 239-290.

Douglas, T. (2000). Basic groupwork (2nd ed.). London, UK: Routledge. Effandi Zakaria, Lu, C. C., \& Md. Yusoff Daud. (2010). The effects of cooperative learning on students' mathematics achievement and attitude towards mathematics. Journal of Social Sciences, 6(2), 272-275.

Felder, R. M., \& Rebecca, B. (2007). Cooperative learning. Retrieved from http://www4.ncsu.edu/unity/lockers/users/f/felder/public/Papers/CLChapt er.pdf Hennessy, D., \& Evans, R. (2006). Small-group learning in the community college classroom. Retrieved from http://www.schoolcraft.edu/pdfs/cce/12.1.93-110.pdf

Jacques, D. (1995). Learning in groups. London, UK: Kogan Page Limited.

Johnson, D. W., \& Johnson R. T. (1991). Learning together and alone: Cooperative, competitive, and individualistic learning (3rd ed.). Needham Heights, MA: Allyn and Bacon.

Johnson, D. W., \& Johnson, R. T. (1994). An overview of cooperative learning. Retrieved from http://www.cooperation.org/pages/overviewpaper.html

Johnson, D., Johnson, R., \& Smith, K. (1991). Cooperative learning: Increasing college faculty instructional productivity. ASHE-Eric Higher Education Report No. 4. Washington, DC: The George Washington University.

Kaenzig, R., Hyatt, E., \& Anderson, S. (2007). Gender differences in college of business educational experiences. Journal of Education for Business, 83(2), 95-100. 
Kennett, D. J., Stedwill, A. T., Berrill, D., \& Young, A. M. (1996). Co-operative learning in a university setting: Evidence for the importance of learned resourcefulness. Studies in Higher Education, 21(2), 177-186.

Kromrey, J. D., \& Purdom, D. M. (1995). A comparison of lecture, cooperative learning and programmed instruction at the college level. Studies in Higher Education, 20(3), 341-349.

Livingston, D., \& Lynch, K. (2000). Group project work and student-centred active learning: Two different experiences. Studies in Higher Education, 25(3), 325345.

Long, M. H., \& Porter, P. A. (1985). Group work, interlanguage talk, and second language acquisition. Retrieved from http://www.jstor.org/journals /tesol.html

McManus, S. M., \& Gettinger, M. (1997). Teacher and student evaluations of cooperative learning and observed interactive behaviors. The Journal of Educational Research, 90(1-6), 13-22.

Panitz, T. (1996). A definition of collaborative vs. cooperative learning. Retrieved from http://www.city.londonmet.ac.uk/deliberation/collablearning/ index.html

Park, C. C. (2001). Learning style preferences of Armenian, African, Hispanic, Hmong, Korean, Mexican, and Anglo students in American secondary schools. Learning Environment Research, 4, 175-191.

Payne, B. K., \& Monk-Turner, E. M. (2006). Students' perceptions of group projects: The role of race, age, and slacking. College Student Journal, 40(1), 132-139.

Smith, A. (2006). Group work benefits pupils, study finds. Retrieved from http://www.guardian.co.uk/education/2006/mar/31/schools.uk2

Terenzini, P. T., Cabrera, A. F., Colbeck, C. L., Parente, J. M., \& Bjorklund, S. A. (2001). Collaborative learning vs. lecture/discussion: Students' reported learning gains. Journal of Engineering Education, 90(1), 123-133.

Tok, H. S. (2006). Cooperative learning and achievement in English language acquisition in a literature class in a secondary school. Retrieved from http://eprints.utm. my/6550/

Vaughan, W. (2002). Effects of cooperative learning on achievement and attitude among students of color. The Journal of Educational Research, 95(6), 359364.

Watson, B. (1995). Relinquishing the lectern: Cooperative learning in teacher education. Journal of Teacher Education, 46(3), 209-215. 